\title{
Radical Polymerization of Methyl Methacrylate by Captodative Substituted Morpholino Succinonitrile
}

\author{
Hitoshi Tanaka, ${ }^{\dagger}$ Yoshihiko TeZuka, and Ken-ichi FuJITA \\ Department of Optical Science and Technology, Faculty of Engineering, \\ Tokushima University, 2-1 Minamijosanjima, Tokushima 770-8506, Japan
}

(Received July 2, 1999; Accepted May 22, 2000)

\begin{abstract}
Radical polymerization of methyl methacrylate (MMA) by captodatively substituted morpholino succinonitrile was studied kinetically at 90 and $130^{\circ} \mathrm{C}$ by comparison with that of styrene. The polymerizations of MMA and styrene at $90^{\circ} \mathrm{C}$ proceeded at moderate rates to give polymers which show unimodal size exclusion chromatography (SEC) curves. Both polymerizations at $130^{\circ} \mathrm{C}$ were significantly fast to give polymers with bimodal SEC curve. A higher molecular weight fraction of the obtained polymer may mostly formed by a spontaneous thermal polymerization in styrene polymerization, but in MMA polymerization produced mainly by dissociation of the domant species. The rate constant of the activation of captodative-capped poly(MMA) domant was smaller than that reported for nitroxide-mediated styrene polymerization.

KEY WORDS Radical Polymerization/Captodative Substitution/Radical Initiator/Bimodal Size Exclusion Chromatography Curve / Morpholino Succinonitrile / Methyl Methacrylate /
\end{abstract}

Controlled molecular weight and narrow polydispersity of polymers have recently been achieved even by the homogeneous radical polymerization systems including nitroxide-mediated stable free radical polymerization (SFRP), ${ }^{1}$ atom transfer radical polymerization (ATRP), ${ }^{2}$ reversible addition-fragmentation chain transfer $(\mathrm{RAFT})^{3}$ polymerization and iniferter polymerization. ${ }^{4} \mathrm{~A}$ number of reagents has been developed in these polymerizations, and the ability to control chain length of polymers and prepare block copolymers much depends on the nature of an end-cappping moiety of polymer. 2,2,6,6-Tetramethylpiperdinyl-1-oxy (TEMPO), ${ }^{1}$ halogen, ${ }^{5}$ phenylseleno, ${ }^{6}$ and dithiocarbamate ${ }^{7}$ moieties are well-known end-capping species of propagating polymer chains in these polymerizations.

Captodative (cd) substitution (geminal substitution of both electron-accepting and -donating groups on the same atom) of monomers, initiators, and chain transfer reagents has been reported to induce unique radical polymerizations because of polarization and radical stabilization effects. ${ }^{8}$ Cd substitution in compounds 1 reduces the bond dissociation energy of the cd substituted $\mathrm{C}-\mathrm{C}$ bond, ${ }^{9}$ i.e., ca. $140-170 \mathrm{~kJ} \mathrm{~mol}^{-1}$, to generate cd substituted carbon radicals which initiate radical polymerizations of various monomers including conjugated and even unconjugated vinyl monomers at moderate temperature. ${ }^{10}$ In previous papers, ${ }^{11}$ molecular weight of the polymer produced increased slowly with reaction time in the polymerization of methyl methacrylate (MMA) in the presence of cd ethane. The cd fragment may be incorporated into propagating polymer chains as an end-capping species to form domant poly(MMA). Faster dissociation of the cd ethanes like 1 should thus induce preferentially the formation of domant, and the dissociation rate of the ethanes may depend much on the electron-withdrawing and-donating powers, as well as steric effect, of the captive and dative groups of the cd ethanes.
In the copolymerizations of various cd substituted olefins amino groups serve as a stronger electron-donating substituent. ${ }^{12}$ Therefore, cd ethanes substituted by amino moiety can be expected to dissociate at higher rates due to stronger cd stabilization of the dissociated radical to give a labile domant although the cd stabilization effect originates basically from the synergistic interaction between electron-withdrawing and -donating moieties and the dissociation rate is also influenced by steric hinderance of an ethane.

In the present work, morpholino succinonitrile 2 was prepared as an amino-substituted cd ethane, and the polymerization of MMA and styrene by 2 was studied kinetically.

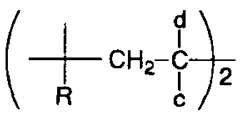

$$
\begin{aligned}
& \mathrm{c}=\mathrm{CN}, \mathrm{COOCH}_{3} \\
& \mathrm{~d}=\mathrm{SC}_{2} \mathrm{H}_{5}, \mathrm{OCH}_{3} \text {, } \\
& \mathrm{R}=\mathrm{CH}_{3}, \mathrm{CN}, \mathrm{COOCH}_{3}, \mathrm{CH} 2 \mathrm{C}\left(\mathrm{CH}_{3}\right)_{3}
\end{aligned}
$$
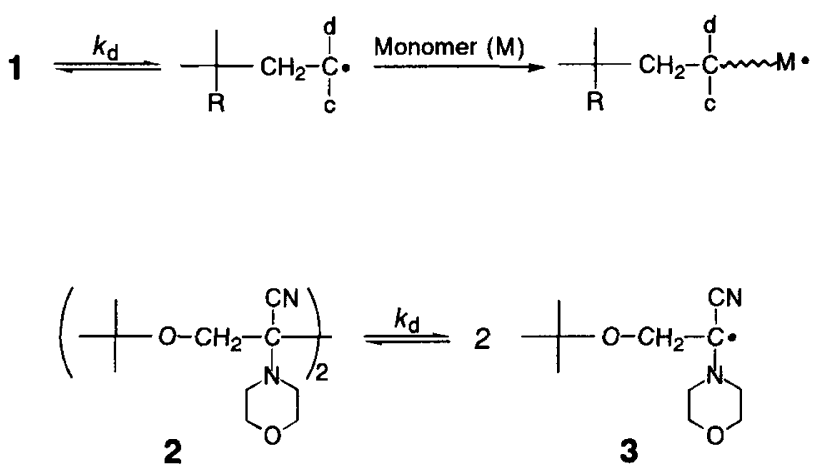

Scheme 1.

\footnotetext{
${ }^{\dagger}$ To whom correspondence should be addressed.
} 


\section{EXPERIMENTAL}

\section{Materials}

2 was prepared by reaction of di-t-butyl peroxide $(2.68 \mathrm{~g}, 20 \mathrm{mmol})$ and $\alpha$-morpholino acrylonitrile ${ }^{13}$ $(3.68 \mathrm{~mL}, 20 \mathrm{mmol})$ in benzene under irradiation of light from a $500 \mathrm{~W}$ high-pressure mercury lamp at ambient temperature. Recrystallization from benzene gave $0.25 \mathrm{~g}$ of purified product (cubic prism) in $5.9 \%$ yield; $m p 177^{\circ} \mathrm{C}$ (decomp.). The structure of $\mathbf{2}$ was determined unequivocally by single crystal X-ray crystallography.

${ }^{1} \mathrm{H}$ NMR $\left(\mathrm{CDCl}_{3}\right)$ of 2: $\delta 4.08\left(\mathrm{~d}, \mathrm{CH}_{2}, 2 \mathrm{H}\right), 4.00(\mathrm{~d}$, $\left.\mathrm{CH}_{2}, 2 \mathrm{H}\right), 3.70\left(\mathrm{t}, \mathrm{CH}_{2}, 8 \mathrm{H}\right), 3.07\left(\mathrm{~m}, \mathrm{CH}_{2}, 8 \mathrm{H}\right), 1.27 \mathrm{ppm}$ (s, $\mathrm{CH}_{3}, 18 \mathrm{H}$ ). Anal. Calcd for $\mathrm{C}_{22} \mathrm{H}_{38} \mathrm{~N}_{4} \mathrm{O}_{4}: \mathrm{C}, 62.60 ; \mathrm{H}$, $9.00 ; \mathrm{N}, 13.30$. Found: C, 62.51; H, 8.88; N, $13.09 \%$.

Commercially available styrene and MMA were purified by ordinary methods. Other reagents and solvents are commercial grade and used without further purification.

\section{Polymerization}

Polymerizations were carried out in a sealed ampoule with shaking at a given temperature. The ampoule containing the required amounts of reagents was degassed several times by freeze-thaw and sealed under vacuum and placed in a constant temperature bath. The resulting polymer was isolated by pouring the contents of the ampoule into a large amount of methanol.

\section{Measurements}

${ }^{1} \mathrm{H}$ NMR spectrum was measured on a JEOL JNM-EX $400(400 \mathrm{MHz})$ spectrometer using tetramethylsilane as an internal standard. X-Ray diffraction of 2 (a colorless prismatic crystal with dimensions of $0.40 \times 0.10 \times$ $0.10 \mathrm{~mm}$ ) was measured with Rigaku RAXIS-RAPID imaging plate diffractometer using graphite monochromated $\mathrm{Cu}-K_{\alpha}$ radiation ( $\lambda=1.54178 \AA$ ) at a temperature of $23^{\circ} \mathrm{C}$ to a maximum $2 \theta$ value of $136.4^{\circ}$. Cell parameters were determined from 2554 reflections at $2 \theta$ of 11.0 $-100.1^{\circ}$. The structure was solved by direct methods and refinement was made by full-matrix least-squares methods. Number- and weight-average molecular weights and number-average degree of polymerization $\left(\bar{M}_{n}, \bar{M}_{w}\right.$, and $\left.\bar{P}_{n}\right)$ of the polymers were determined by SEC using a Tosoh HLC-8020 (columns: TSK gel$\left.\mathrm{G} 7000 \mathrm{H}_{\mathrm{HR}}+\mathrm{G}_{5000 \mathrm{H}_{\mathrm{HR}}}+\mathrm{G} 3000 \mathrm{H}_{\mathrm{HR}}\right)$ in $0.1 \% \mathrm{~N}, \mathrm{~N}$-dimethylformamide solution based on a standard polystyrene at $45^{\circ} \mathrm{C}$. Quantitative analysis in SEC for rate determination was performed by using internal standard polystyrene with $\bar{M}_{n}=1.03 \times 10^{6}$ and $\bar{M}_{w} / \bar{M}_{n}=1.01$. ESR spectrum was recorded on a JEOL JES-RE1X spectrometer operating at $\mathrm{X}$ band $(9.5 \mathrm{GHz})$ with a TE mode cavity. The temperature of ESR cavity was controlled by a JEOL ES-DVT3 controller. Hyperfine splitting constant (a) and $g$ value were determined by comparison with those of $\mathrm{MnO}$.

The rate constant of decomposition $\left(k_{\mathrm{d}}\right)$ of 2 was estimated by tracing the consumption of a radical-trapping reagent, diphenyl picrylhydrazyl (DPPH), in degassed acetonitrile solution of $2\left([\boldsymbol{2}]=5.0 \times 10^{-3} \mathrm{~mol} \mathrm{~L}^{-1}\right)$ by UV spectrophotoscopy.

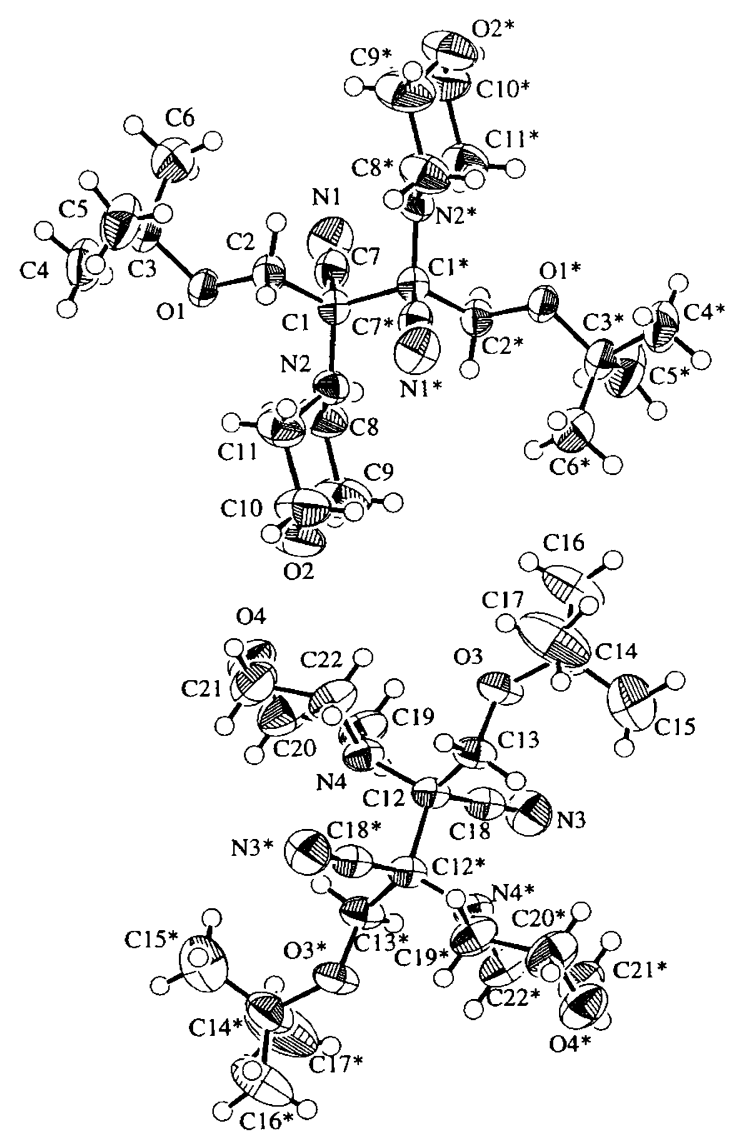

\begin{tabular}{llll}
\multicolumn{5}{c}{ Selected geometric parameters } \\
$\mathrm{C} 1-\mathrm{C} 1^{*}$ & $1.600(6) \AA$ & $\mathrm{C} 12-\mathrm{C} 12^{*}$ & $1.596(6) \AA$ \\
$\mathrm{C} 1-\mathrm{C} 2$ & $1.535(4) \AA$ & $\mathrm{C} 12-\mathrm{C} 13$ & $1.541(4) \AA$ \\
$\mathrm{C} 1-\mathrm{N} 2$ & $1.473(4) \AA$ & $\mathrm{C} 12-\mathrm{C} 18$ & $1.488(5) \AA$ \\
$\mathrm{C} 1-\mathrm{C} 7$ & $1.486(5) \AA$ & $\mathrm{C} 12-\mathrm{N} 4$ & $1.470(4) \AA$ \\
$\mathrm{C} 1{ }^{*}-\mathrm{C} 1-\mathrm{C} 2$ & $110.0(3)^{\circ}$ & $\mathrm{C} 12^{*}-\mathrm{C} 12-\mathrm{C} 13$ & $110.5(3)^{\circ}$ \\
$\mathrm{C} 1^{*}-\mathrm{C} 1-\mathrm{C} 7$ & $106.0(3)^{\circ}$ & $\mathrm{C} 12^{*}-\mathrm{C} 12-\mathrm{C} 18$ & $106.1(3)^{\circ}$ \\
$\mathrm{C} 1^{*}-\mathrm{C} 1-\mathrm{N} 2$ & $109.1(3)^{\circ}$ & $\mathrm{C} 12^{*}-\mathrm{C} 12-\mathrm{N} 4$ & $109.8(3)^{\circ}$
\end{tabular}

Figure 1. ORTEP view of $\mathbf{2}$ with atomic numbering. Symmetry code: $\left(^{*}\right)$.

\section{RESULTS AND DISCUSSION}

\section{Decomposition of Initiator}

Structural analysis of $\mathbf{2}$ by X-ray diffraction indicated meso forms of $\mathbf{2}$ and anti-position of each morpholino group as seen in Figure 1. ${ }^{14}$ Long bond length (1.600 and $1.596 \AA$ ) between cd substituted $\mathrm{C}-\mathrm{C}$ bond is particularly interesting in studing bond dissociation, and such a bond is expected to dissociate smoothly. From plots of induction period ( $\left.t_{\text {ind }}\right)$ against initial DPPH concentration $\left([\mathrm{DPPH}]_{0}\right)$, the rate constants of dissociation $\left(k_{\mathrm{d}}\right)$ of 2 at $55,60,65$, and $70^{\circ} \mathrm{C}$ were estimated to be 2.98 $\times 10^{-6}, 7.46 \times 10^{-6}, 1.23 \times 10^{-5}$, and $1.59 \times 10^{-5} \mathrm{~s}^{-1}$, respectively, according to the equation of $[\mathrm{DPPH}]_{0} / t_{\text {ind }}=$ $2 k_{\mathrm{d}}[2]$ at the concentrations of $[2]=5.0 \times 10^{-3} \mathrm{~mol} \mathrm{~L}^{-1}$ and $[\mathrm{DPPH}]=5.0 \times 10^{-5} \mathrm{~mol} \mathrm{~L}^{-1}$ in acetonitrile. From 55 to $70^{\circ} \mathrm{C}$, activation energy $\left(E_{\mathrm{d}}\right)$ of the dissociation of 2 was $103.7 \mathrm{~kJ} \mathrm{~mol}^{-1}$ from the slope in Figure 2 according 


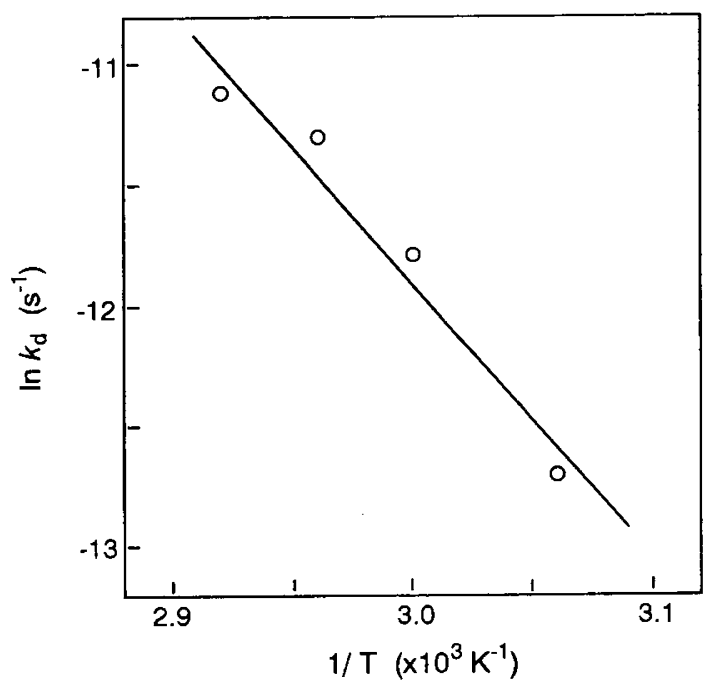

Figure 2. Dependency of rate constant of dissociation $\left(k_{\mathrm{d}}\right)$ of $\mathbf{2}$ on temperature. $[2]=5.0 \times 10^{-3} \mathrm{~mol} \mathrm{~L}^{-1}$ in acetonitrile.

Table I. Bulk polymerizations of MMA and styrene by $\mathbf{2}$

\begin{tabular}{lccc}
\hline \multirow{2}{*}{ Monomer } & \multirow{2}{*}{ initiator $^{\text {a }}$} & \multicolumn{2}{c}{ Yield $/ \%$} \\
\cline { 3 - 4 } & & $90^{\circ} \mathrm{C}(70 \mathrm{~min})$ & $130^{\circ} \mathrm{C}(20 \mathrm{~min})$ \\
\hline Styrene & $\mathbf{2}$ & 17.4 & 21.6 \\
Styrene & None & 1.0 & 8.9 \\
MMA & $\mathbf{2}$ & 78.4 & 26.1 \\
MMA & None & 1.0 & 0.1 \\
\hline
\end{tabular}

${ }^{a}[\mathbf{2}]=5.0 \times 10^{3} \mathrm{~mol} \mathrm{~L} \cdot$ '.

to the Arrhenius equation. $E_{\mathrm{d}}$ obtained for $\mathbf{2}$ as well as $\mathbf{1}$ (104.6 kJ mol $\mathrm{kor}^{-1} \mathrm{c}=\mathrm{CN}, \mathrm{d}=\mathrm{SC}_{2} \mathrm{H}_{5}$, and $\mathrm{R}=\mathrm{CN}$ ) is lower than other cd ethanes, ${ }^{10}$ but higher than that of phenyl-substituted ethanes including tetraphenylsuccinonitrile $\left(94.1 \mathrm{~kJ} \mathrm{~mol}^{-1}\right)$ and tetrakis(4-chlorophenyl) succinonitrile $\left(65.3 \mathrm{~kJ} \mathrm{~mol}^{-1}\right) .^{15}$

ESR spectrum observed by pyrolysis of 2 at $130^{\circ} \mathrm{C}$ suggests the formation of radical 3 with the parameters: $a_{\beta-\mathrm{H}}=1.02, a_{\beta-\mathrm{N}}=0.79, a_{\gamma-\mathrm{H}}=0.71$, and $a_{\gamma-\mathrm{N}}=0.29 \mathrm{mT}$ $(g=2.0037)$, which are similar to those of the cd radical bearing cyano-2-propyl group instead of $t$-butoxy one on 2: $a_{\beta-\mathrm{H}}=1.012, a_{\beta-\mathrm{N}}=0.79, a_{\gamma-\mathrm{H}}=0.712$, and $a_{\gamma-\mathrm{N}}=0.294$ $\mathrm{mT}(g=2.0032){ }^{16}$

\section{Polymerization}

Polymerizations of styrene and MMA with 2 were carried out in bulk at 90 and $130^{\circ} \mathrm{C}$. From Table I, 2 greatly accelerates both polymerizations, in particular the polymerization of MMA, compared with other cd ethanes and phenyl-substituted ethanes. ${ }^{17}$ Such higher acceleration of vinyl polymerizations by 2 may arise from higher dissociation rate of $\mathbf{2}$ among cd ethanes and higher addition reactivity of 3 to vinyl monomers due to less persistency of 3 than phenyl-substituted methyl radicals. Appropriate cd stabilization and steric effects due to morpholino substituent would appear important in such high initiation ability of 2 .

Figure 3 shows plots of polymer yield against reaction time in the polymerizations of MMA and styrene at 90 and $130^{\circ} \mathrm{C}$, from which the polymer yields are found to

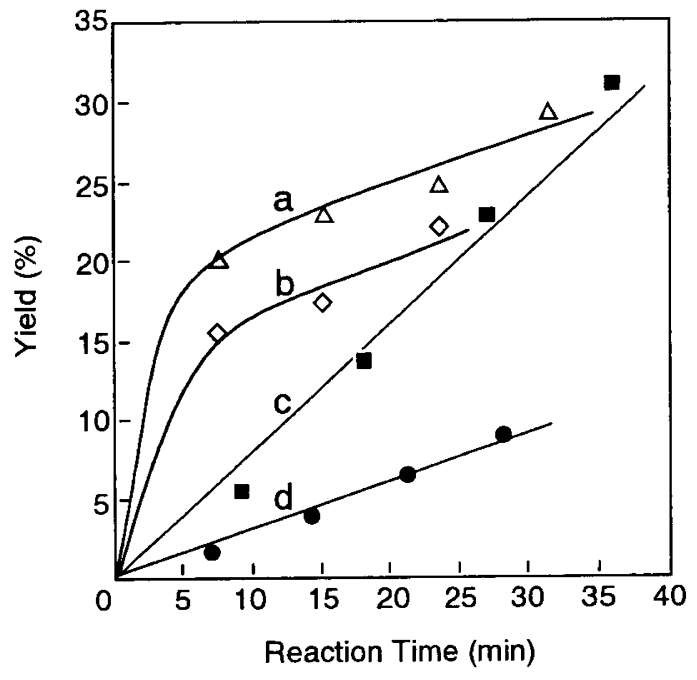

Figure 3. Time-yield curves in bulk polymerizations of MMA and styrene with 2 at 90 and $130^{\circ} \mathrm{C}$. MMA at 130 (a) and $90^{\circ} \mathrm{C}$ (c), and styrene at $130(\mathrm{~b})$ and $90^{\circ} \mathrm{C}(\mathrm{d})$ in $[2]=5.0 \times 10^{-3} \mathrm{~mol} \mathrm{~L}^{-1}$.<smiles>COC(=O)C(C)(CCCCC(C)(CC(C#N)(COC(C)(C)C)COC(C)(C)C)N1CCOCC1)C(=O)OC</smiles>

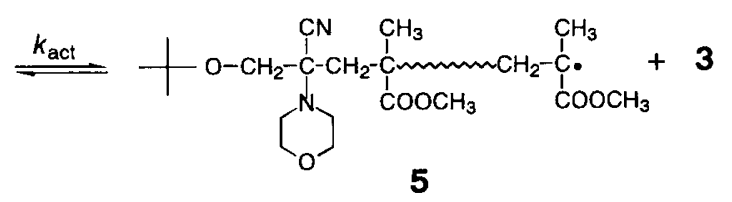

Equation 1.

increase linearly as a function of reaction time without induction period at $90^{\circ} \mathrm{C}$ as seen in Figure $3 \mathrm{c}$ and $3 \mathrm{~d}$. Such plots for polymerizations at $130^{\circ} \mathrm{C}$ give no straight line, i.e., rapid polymerization in the initial stage of the polymerization, followed by slow polymerization, in both polymerizations of styrene and MMA as seen in Figure $3 \mathrm{a}$ and $3 \mathrm{~b}$. To confirm such polymerizations each giving a curved time-yield relationship, molecular weight of the polymers produced was measured by SEC in the polymerizations of MMA and styrene with 2 at various reaction times at $130^{\circ} \mathrm{C}$ as shown in Figure 4. In MMA polymerization in this Figure a lower molecular weight (LM) polymer with a unimodal SEC curve $\left(\bar{M}_{n}=4.14 \times\right.$ $10^{4}$ and $\bar{M}_{w} / \bar{M}_{n}=2.06$ ) produced in the initial stage of the polymerization is deformed gradually into a higher molecular weight (HM) polymer $\left(\bar{M}_{n}=4.23 \times 10^{5}\right.$ and $\bar{M}_{w} / \bar{M}_{n}=1.36$ ) with increasing conversion. In polymerization at $90^{\circ} \mathrm{C}$, an apparent unimodal SEC curve was observed in contrast to the polymerization at $130^{\circ} \mathrm{C}$. Increase in HM polymer yield with reaction time was also observed in styrene polymerization as seen in Figure 4.

Figure 5 shows the relationship between reaction time 

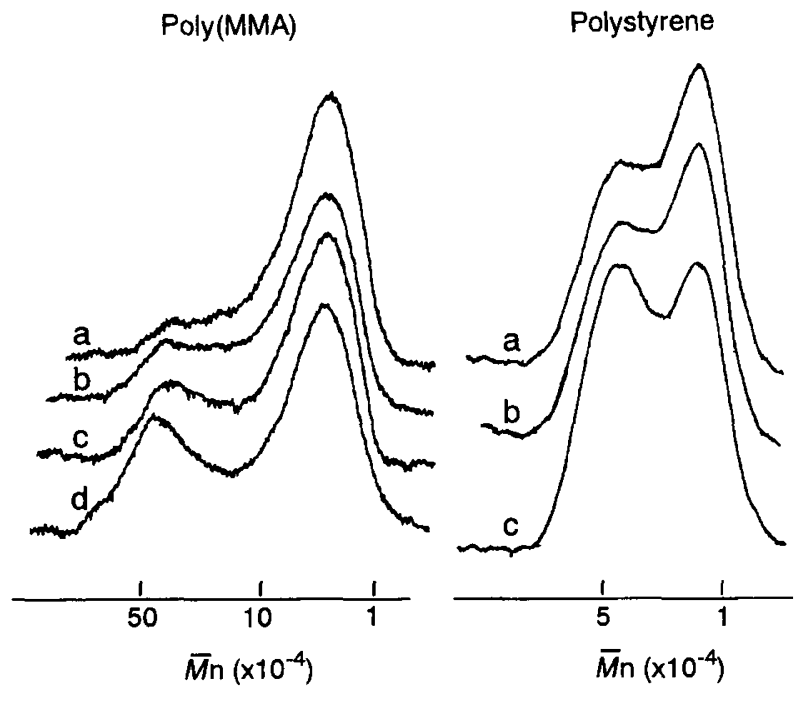

Figure 4. Variation in SEC curves with reaction time in bulk polymerizations of MMA and styrene at $130^{\circ} \mathrm{C}$. Reaction time is 8 (a), 16 (b), 24 (c), and $32 \mathrm{~min}(\mathrm{~d})$.

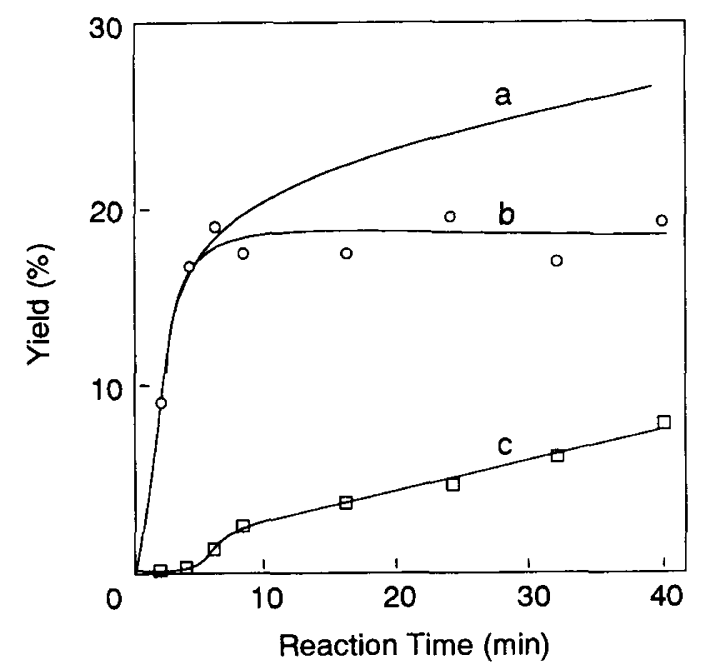

Figure 5. Variation in polymer yield with reaction time in bulk polymerization of MMA at $130^{\circ} \mathrm{C}$. Yields of total polymer (a), lower molecular weight polymer (b), and higher molecular weight polymer $(\mathbf{c})$.

and yields of total, HM, and LM polymers in MMA polymerization at $130^{\circ} \mathrm{C}$. The slope observed after polymerization time of ca. $5 \mathrm{~min}$ in Figure $3 \mathrm{a}$ was similar to that observed in Figure $5 \mathrm{c}$. That is, the polymerization continued after ca. $5 \mathrm{~min}$ is mainly due to the conversion of LM polymer into HM polymer through a dissociation of the domant species 4 (eq 1) capped with the cd fragment. In fact, the polymerization of MMA in the presence of domant poly(MMA) prepared independently by MMA polymerization with 2 for $2 \mathrm{~min}$ at $130^{\circ} \mathrm{C}$ gave a polymer with a bimodal SEC curve in moderate yield after reaction time of $20 \mathrm{~min}$ at $130^{\circ} \mathrm{C}$.

From variation in the number of polymer chains dur- ing MMA polymerization, the activation rate constant $\left(k_{\text {act }}\right)$ of the domant species was roughly calculated as 1.0 $\times 10^{-5} \mathrm{~s}^{-1}$ according to $\ln \left([4]_{0} /[4]_{\mathrm{t}}\right)=k_{\text {act }} t$, in which $[4]_{0}$ and $[4]_{\mathrm{t}}{ }^{18}$ are the concentrations of 4 in the begining (at reaction time of $5 \mathrm{~min}$ ) and following polymerization time $t$, and $[4]_{0}=4.31 \times 10^{-3} \mathrm{~mol} \mathrm{~L}^{-1} .{ }^{19}$ Measurement of HM polymer amounts by the SEC curve-resolution method in the polymerization with 2 also gives $k_{\text {act }}$ of 2.5 $\times 10^{-6}(n=2) \sim 5.0 \times 10^{-6}(n=1) \mathrm{s}^{-1}$ approximately according to the equation for conventional radical polymerization, $R_{\mathrm{p}}{ }^{2}=\left(k_{\mathrm{p}}{ }^{2} / k_{\mathrm{t}}\right) n k_{\text {act }}[4]_{0}[\mathrm{MMA}]^{2}$, in which the ratio of rate constants of elementary reactions $\left(k_{\mathrm{p}}{ }^{2} / k_{\mathrm{t}}\right)=$ $1 / 13.6,{ }^{20}$ number of the radicals (dissociated from a domant) giving $\mathrm{HM}$ polymer $(n)=1$ or $2,100 \%$ reinitiation efficiency, $[\mathrm{MMA}]=7.61 \mathrm{~mol} \mathrm{~L}{ }^{-1}$ at polymerization time of $5 \mathrm{~min}$ (19\% conversion), and polymerization rate $\left(R_{\mathrm{p}}\right)$ $=3.04 \times 10^{-4} \mathrm{~mol} \mathrm{~L}^{-1} \mathrm{~s}^{-1}$ from curve (c) in Figure 5. Difference in $k_{\text {act }}$ may arise from polystyrene-calibrated SEC, experimental error due to small $k_{\text {act }}$ and small increase in the number of polymer chains (1.9\% after polymerization time of $40 \mathrm{~min}$ ), side reactions, ${ }^{21,22}$ and so on.

$k_{\text {act }}$ obtained in this study was much smaller than that reported for TEMPO-capped polystyrene $\left(k_{\text {act }}>10^{-3} \mathrm{~s}^{-1}\right),{ }^{23}$ probably because of lesser stability of $\mathbf{3}$. Therefore, it is easily recognized that the number-average degree of polymerization $\left(\bar{P}_{n}\right)$ in the reinitiated polymerization with 3 and/or $5\left(\bar{P}_{n}>c a .1700\right)$ is much larger than that in SFRP of styrene with TEMPO $\left(\bar{P}_{n}=c a .20\right),{ }^{23}$ which seems to bring about such a bimodal curve.

In styrene polymerization, the yield of LM polymer little varied after polymerization time of $c a .5 \mathrm{~min}$ and yield and molecular weight $\left(\bar{M}_{n}=5.3 \times 10^{4}\right)$ of HL polymer were similar to those $\left(\bar{M}_{n}=6.5 \times 10^{4}\right)$ of the polymer formed by spontaneous polymerization. The cd-fragment capped polystyrene produced in the initial stage of the polymerization may thus mostly remain as a dead polymer without further dissociation although more detailed study is necessary. In this case, smaller steric hindrance due to $\alpha$-monosubstituted polystyrene, in contrast to $\alpha$, $\alpha$-disubstituted poly(MMA), may bring about stronger terminal $\mathrm{C}-\mathrm{C}$ bonds, as already elucidated by X-ray diffraction of a model compound for polystyrene capped with diphenyl methane ${ }^{24}$ and actual SFRP of styrene and MMA with nitroxides. ${ }^{25}$

\section{CONCLUSION}

In the present work cd ethane 2 initiated effectively the radical polymerization of MMA to give a domant species, and domant poly(MMA) produced dissociated again to initiate vinyl polymerization at $130^{\circ} \mathrm{C}$. The activation rate constant of cd-capped poly(MMA) domant was much smaller than those reported for nitroxide $-{ }^{26}$ and halogen $(>0.045)^{27}$-capped polystyrene domants, which seems to bring about the bimodal SEC curve for cd-capped poly(MMA) .

Acknowledgment. We thank Dr. M. Shiro, Rigaku Corp., for measurement of X-ray diffraction. 


\section{REFERENCES AND NOTES}

1. D. H. Solomon, E. Rizzardo, and P. Calioli, Eur. Pat. Appl. 135280 1985: Chem. Abstr., 102, 221335q (1985); M. K. Georges, R. P. N. Veregin, P. M. Kazmaier, and G. K. Hamer, Macromolecules, 26, 2987 (1993).

2. J. -S. Wang and K. Matyjaszewski, Macromolecules, 28, 7901 (1995).

3. J. Chiefari, Y. K. B. Chong, F. Ercole, J. Krstina, J. Jeffery, T. P. T. Le, R. T. A. Mayadunne, G. F. Meijs, C. L. Moad, G. Moad, E. Rizzardo, and S. H. Thang, Macromolecules, 31, 5559 (1998).

4. T. Otsu and M. Yoshida, Makromol. Chem., Rapid Commun., 3, 127 (1982)

5. M. Kato, M. Kamigaito, M. Sawamoto, T. Higashimura, Macromolecules, 28, 1721 (1995).

6. T. S. Kwon, S. Kumazawa, T. Yokoi, S. Kondo, H. Kunisada, and Y. Yuki, J. Macromol. Sci., Pure Appl. Chem., A34, 1553 (1997).

7. T. Otsu, T. Matsunaga, A. Kuriyama, and M. Yoshioka, Eur. Polym. J., 25, 643 (1989).

8. H. Tanaka, I. Sakai, and T. Ota, J. Am. Chem. Soc., 108, 2208 (1986); H. Tanaka, Y. Yasuda, and T. Ota, J. Chem. Soc., Chem. Commun., 109 (1986).

9. H. Tanaka, Trends Polym. Sci., 1, 361 (1993); 4, 106 (1996).

10. H. Tanaka, Y. Teraoka, T. Sato, and T. Ota, Makromol. Chem., 194, 2719 (1987).

11. H. Tanaka, T. Kameshima, and T. Hongo, J. Polym. Sci., Part A: Polym. Chem., 34, 1945 (1996).

12. J. Penelle, A. B. Padias, H. K. Hall, Jr., and H. Tanaka, Adv. Polym. Sci., 102, 73 (1992).

13. S. C. Temin, J. Org. Chem., 22, 1714 (1957).

14. Two crystallographically independent molecules exist in a unit cell lying on the inversion center of the crystal. Crystal data: $\mathrm{C}_{22} \mathrm{H}_{38} \mathrm{O}_{4} \mathrm{~N}_{4}, F . W .=422.57$, primitive triclinic, $\mathrm{P1}(\# 2)$, $a=10.437(1) \AA, b=19.451(3) \AA, c=6.531(1) \AA, \alpha=91.52(1)^{\circ}$, $\beta=105.42(1)^{\circ}, \gamma=101.77(1)^{\circ}, V=1246.8(3) \AA^{3}, Z=2, D_{\text {calcd }}=$ $1.126 \mathrm{~g} \mathrm{~cm}^{-3}, F_{000}=460.00, \mu\left(\mathrm{Cu}-K_{\alpha}\right)=6.28 \mathrm{~cm}^{-1}$.

15. D. Braun, T. Skrzek, S. S. BeiBer, and H. Tretner, Makromol. Chem. Phys., 196, 573 (1995).

16. L. Stella, Z. Janousek, R. Merenyi, and H. G. Viehe, Angew. Chem. Int. Ed. Engl., 17, 691 (1978).
17. H. Tanaka, Prog. Polym. Sci., 17, 1107 (1992).

18. It is difficult to determine precisely the value of $[4]_{t}$ because of very small variation in domant concentration during polymerization and large scatter of experimental points as seen in curve (b) in Figure 5. It was thus estimated based on the number of HM polymer chains produced, termination mode, and the assumption that 3 and 5 give HM polymer with $100 \%$ reinitiation efficiency and a bimolecular termination of reinitiated poly(MMA) radicals. $[4]_{\mathrm{t}}$ was calculated to be $4.22 \times$ $10^{-3} \mathrm{~mol} \mathrm{~L}^{-1}$ at $t=35 \mathrm{~min}$ on the basis of the number of HM polymer chains generated $(4.1 \%$ increase based on the original LM polymer chains) and $12 \%$ recombination termination at $130^{\circ} \mathrm{C}$ (calculated from the reference ${ }^{22}$ ).

19. It is not easy to determine precisely the content of end-capped morpholino fragments from ${ }^{1} \mathrm{H}$ NMR spectra of domant poly(MMA) at present because of very small content of cd fragment in polymer and overlapping of ${ }^{1} \mathrm{H}$ NMR absorption of the morpholino units with very strong absorption of methoxy protons of poly(MMA) in the region of $2.5-4.0 \mathrm{ppm}$ although some absorptions probably due to morpholino units appeared around $2.7-3.0$ and $3.6 \mathrm{ppm}$ in ${ }^{1} \mathrm{H}$ NMR of domant poly(MMA- $\left.d_{8}\right)$. Thus, $[4]_{0}$ was estimated from polymer yield $(19 \%)$ and molecular weight $\left(\bar{M}_{n}=4.14 \times 10^{4}\right)$.

20. Calculated from $\left(k_{\mathrm{t}} / k_{\mathrm{p}}{ }^{2}\right)=4.65 \times 10^{-3} \exp (6390 / R T)$, where $R$ and $T$ are the gas constant and absolute temperature, respectively: A. V. Tobolsky, J. Polym. Sci., 16, 311 (1955).

21. C. Plessis, G. Arzamendi, J. R. Leiza, H. A. S. Schoonbrood, D. Charmot, and J. M. Asua, Macromolecules, 33, 4 (2000).

22. Side reaction of the unsaturated end group produced by high disproportionation termination of polymers at high temperature such as $130^{\circ} \mathrm{C}$ : G. Henrici-Olive and S. Olive, Makromol. Chem., 31, 88 (1959).

23. D. Greszta and K. Matyjaszewski, Macromolecules, 29, 7661 (1996).

24. D. Braun, H. J. Lindner, and H. Tretner, Eur. Polym. J., 25, 725 (1989).

25. G. Moad and D. H. Solomon, "The Chemistry of Free Radical Polymerization", 1st ed, Pergamon, Oxford, 1995.

26. A. Goto, T. Terauchi, T. Fukuda, and T. Miyamoto, Macromol. Rapid Commun., 18, 673 (1997).

27. K. Ohno, A. Goto, T. Fukuda, J. Xia, and K. Matyjaszewski, Macromolecules, 31, 2699 (1998). 